\title{
Improve the Quality of Higher Education Through Leadership Roles and Organizational Culture
}

\author{
Onisimus Amtu ${ }^{1}$, Fakhruddin $^{2}$, Haryono $^{3}$, Muhsin $^{4}$ \\ \{amtuonisimus@gmail.com¹, fkhruddin@mail.unnes.ac.id² \\ Faculty of Science Christian Education, Ambon State Christian Religion Institute ${ }^{1}$ \\ Faculty of Science Education, Semarang State University 2,3
}

\begin{abstract}
Higher education requires a leadership role and organizational culture in order to encourage the implementation of an internal quality assurance system properly. This study aims to examine the influence of leadership (L) and organizational culture (OC) on the implementation of the internal quality assurance system (IQAS) at state universities. This study uses quantitative methods with survey techniques involving 221 respondents from 3 public universities in the city of Ambon. Data collection uses a questionnaire with descriptive and inferential statistical data analysis techniques. It was found that (L) and (OC) influenced the implementation of (IQAS) in universities. The magnitude of the influence of (L) on (IQAS) implementation is $46.7 \%$. The influence of (OC) on the implementation of (IQAS) in college is $58.9 \%$. While the influence of (L) and (OC) on the implementation of (IQAS) in state universities is $59 \%$.
\end{abstract}

Keywords: Leadership, Organizational Culture, Implementation IQAS

\section{Introduction}

Community demands on the quality of higher education as a result of globalization are concrete problems whose solutions can not be delayed[1]. Higher education plays a role in increasing the nation's competitiveness in facing globalization in all fields[2]. Today's quality is a excellent, which is often discussed by various institutions in order to guarantee its existence in global competition[3]. Universities are responsible for providing quality assurance to the public[4]. This is important because the quality of higher education is the level of compatibility between the implementation of higher education and higher education standards[5] through an internal quality assurance system[6], [7]. With the aim of ensuring the fulfillment of systemic standards of higher education, the quality culture is aligned and develops in the individual leaders and organizational actors[8], [9]. But in reality there are still various problems because they have not touched the other quality points[10]. Improving the quality of education so far has not been in line with expectations because it tends to be regulated by bureaucracy at the central level [11] and the performance of quality assurance in higher education has not been effective it is felt to be caused by the politics of campus organizations[12]. The success of organizational quality control is very dependent on the ability and attitude of the management because the core of institutional leadership is convincing, directing, empowering, arousing confidence, and providing support to all parties[13], [14] and managerial ability becomes important to influence subordinates to maximize organizational performance, quality and innovation to support organizational goals[15], [16]. 
In addition to leadership, organizational culture factors can encourage the realization of higher education quality through communication, motivation and leadership[17], including structure, culture, human resource management and leadership [18], external environment, labor, managers and leader, structure, technology, organizational history, and future perceptions[19]. Culture relates to the informal aspects of the organization and focuses on values, beliefs and individual norms in the organization and becomes a shared meaning[20], [21]. But previous studies examining the influence of leadership and organizational culture on the implementation of quality assurance systems in tertiary institutions have not been studied in the open literature. Thus, this study will examine whether there is an influence of leadership (L) (H1) on the implementation of the internal quality assurance system (IQAS), is there an influence of organizational culture (OC) $(\mathrm{H} 2)$ on the implementation of the internal quality assurance system (IQAS), and the influence (L) and (OC) (H3) together towards implementation (IQAS) in state universities.

\section{Method}

This study uses a quantitative method with a correlational design using survey types to determine the effect of one variable with another variable. Three variables studied are; leadership (L) (X1), organizational culture (OC) (X2) and implementation of an internal quality assurance system (IQAS) (Y). Data collection uses a questionnaire with a rating scale to get respondents' answers or attitudes towards a situation that is observed and experienced. Descriptive analysis techniques are calculated mean, median, mode, standard deviation, range, minimum score, and maximum score. Category score, required to calculate interval classes. Furthermore, inferential analysis techniques with parametric statistical models for simple regression analysis and multiple regression with the help of SPSS 2. for windows. Referring to the Slovin formula with a rate of $5 \%$ for a population of 340 , the study sample consisted of 221 respondents selected at 3 state universities in the city of Ambon - Maluku.

\section{Results and Discussion}

\subsection{Results}

After being analyzed descriptively, the mean was 128.75; the standard deviation was 5,200 , the variance was 27,036 of the leadership variables. The organizational culture variable obtained a mean value of 128.57 , a standard deviation of 6.406 , and a variance of 41.036 . The variable implementation of the internal quality assurance system obtained a mean of 128.51 , a standard deviation of 8,155 , and a variance of 66,509

Leadership and Implementation IQAS. The results of testing the influence hypothesis (L) on the implementation (IQAS) obtained a value $\left(b_{1}\right)=9,559$ and $b_{0}=1,072$, thus forming a regression equation $Y=9,559+1,072 \mathrm{X}_{1}$. Since $H_{0}$ is rejected and $H_{a}$ is accepted, it is concluded that there is significant influence (L) towards (IQAS). Simple linear coefficient test obtained by $\mathrm{t}_{\text {count }}>\mathrm{t}_{\text {table }}$ or 9.737> $>1.65$ means that there is influence (L) on (IQAS). Correlation coefficient analysis shows the existence of a correlation coefficient of $R=0.684$ and a determination coefficient of 0.467 or $46.7 \%$. So it can be concluded that $46.7 \%$ of implementation (IQAS) is influenced by (L) while the remaining $53.3 \%$ affects by other factors. 
Organizational Culture and IQAS. Testing the influence hypothesis (OC) on the implementation (IQAS) obtained a value $(\mathrm{b} 1)=2.897$ and $\mathrm{b}_{0}=0.977$, with the form of a simple linear regression equation $\hat{Y}=2.897+10.111 \mathrm{X}_{2}$. It was concluded that because $H_{0}$ was rejected and $H_{a}$ was accepted, it was decided that there was a significant influence (OC) on implementation (IQAS. Simple linear coefficient test obtained $t_{\text {count }}>t_{\text {table }}$ or 12.439>1.65 means there was influence (OC) on implementation (IQAS). obtained a value of $R=0.767$ and a determination coefficient of 0.589 or $58.9 \%$. It was concluded that $58.9 \%$ (IQAS) was influenced by (OC) while the remaining $41.1 \%$ influenced by other factors.

Leadership, Organizational Culture and IQAS. Testing the hypothesis of influence (L) and (OC) on implementation (IQAS) using a simple regression analysis of the values $\mathrm{b}_{0}=0.548, \mathrm{~b}_{1}$ $=0.091$ and $b_{2}=0.912$ so that the regression model is $\hat{Y}=0.548+0.091 \mathrm{X}_{1}+0.912 \mathrm{X}_{2}$. The model shows that: (a) every increase in one score (L) will be followed by an increase in implementation (IQAS) of 0.091 , if other variables are considered constant, and (b) each increase in one score (OC) will be followed by an increase in implementation (IQAS ) amounting to 0.912 , if other variables are considered permanent. Furthermore, the significance test of the regression equation and the regression coefficient obtained $F_{\text {count }} 76,899$. While the value of $F_{\text {table }}$ with a significant level of $\alpha=0.05 \mathrm{dk}=110-2=108$, then obtained the value of $\mathrm{F}_{\text {table }}=2.68$. It turns out that $\mathrm{F}_{\text {count }}>\mathrm{F}_{\text {table }}$ or $76,899>2.68$, then $H_{0}$ is rejected and $H_{a}$ is accepted meaning significant or there is influence (L) and (OC) on implementation (IQAS). Then the correlation coefficient test obtained the value of $R=0.768$ and the determination coefficient of 0.590 or $59 \%$. It can be concluded that $59 \%$ of implementation (IQAS) is influenced by (L) and (OC) while the remaining $40.1 \%$ is influenced by other factors.

\subsection{Discussions}

Leadership. The results of the statistical data analysis showed that (L) had a strong influence on implementation (IQAS) in higher education. The magnitude of the effect can be proven by the magnitude of the coefficient of determination of $46.7 \%$. Leadership is certainly the deciding factor that drives the organization. A leader successfully achieves the goals and pursues the specified target achievement. With his competence, he built the commitment of all parties to collaborate to improve education competitiveness. The priority measures offered are top priority to requirements and a high level that meets the requirements in an era of increasingly stringent competitiveness. Without a strong leadership commitment, the quality of each tertiary institution is limited to document design that is difficult to realize. Leadership is not just a matter of position, but a moral obligation that bears a person to ensure the quality of higher education continues to increase every time. This finding is in line with previous studies which found that (L) has a positive effect and is associated with exemplary, authority, skills, information delivery, and decision making. Greater leadership and leadership will encourage employees to do something for the quality of academic services [22], [23], [24], [25], [26], [27].

Organizational Culture. Data analysis showed that (OC) had an effect on implementation (IQAS). The magnitude of the effect is stated by the magnitude of the determination coefficient of $58.9 \%$. Organizational culture has an important role in every university. Organizational culture requires effective and dynamic communication patterns to connect the interests of all parties in order to be able to build cooperation and partnerships in synergy and simultaneously. Based on high work motivation and supported by innovative and creative leadership styles and patterns, the quality of higher education will improve. A dynamic organizational culture is 
characterized by the emergence of creativity and innovation of each individual that develops in a dynamic and professional academic atmosphere and climate. Every university needs to pay attention to the balance of academic culture and creativity and innovation that develops so as to support the quality of education, research and community service. This finding is relevant to the results of previous studies which showed that there was a positive contribution of (OC) variables to quality assurance in higher education. (OC) has migrated towards a more responsive culture and is increasingly supported by various groups of internal and external stakeholders so that it can have a significant influence on the performance of employees, teachers and lecturers [28], [29], [30], [31], [32], [33], [34].

Leadership and Organizational Culture. Statistical test results show that $59 \%$ of implementation (IQAS) in state higher education is influenced by leadership and organizational culture. The results of this analysis indicate that the leadership factor is always related to creating a healthy, dynamic and developing organizational culture. Both hold important roles as dynamists in organizations. The university framework towards achieving quality requires systems and organizational management that provide space and facilities for the development of a measurable and planned academic atmosphere. Leaders encourage the creation of culture in each faculty so that lecturers and students can work together to create technological works and apply knowledge widely. This principle is not limited to state universities but is a necessity for all educational organizations to produce professional graduates and help overcome various problems in society. The failure of leaders and the low organizational culture, will have a negative influence on the management performance of each tertiary institution. Even more surprising is the loss of public confidence and other stakeholders in state higher education. This finding is in line with the results of previous studies which showed that there were positive contributions to (L) variables on (OC), and lecturers' competencies in the role of administrators in quality assurance in higher education. A leader can encourage intellectual growth of both staff students and that creates a culture of learning easier for higher education institutions to uphold high quality standards [35], [36], [37], [38], [39].

\section{Conclusion}

The findings of this study prove IQAS is very important by leadership factors and organizational culture. Leadership in every university needs to pay attention to quality improvement through the application of IQAS. The leader is obliged to mobilize the resources owned by the university to obtain the agreed quality. Besides the L factor, it turns out OC has a major contribution to the application of IQAS. OC adjusts the academic adopted and becomes general norms and standards. A dynamic and creative $\mathrm{OC}$ will encourage individuals to improve their abilities, compete fairly and improve professional academic services. Professional quality $\mathrm{L}$ and $\mathrm{OC}$ that are healthy, dynamic, creative and innovative will have a positive impact on the implementation of IQAS. Getting rid of leaders who focus on improving quality will create an academic culture that allows all elements to collaborate and build partnerships for the advancement of education in Indonesia.

Acknowledgments. Thanks and awards were presented to the Rector and academic staff of Ambon University Pattimura, Rector and academic staff of the Ambon State Christian Religion 
Institute, and the Director and academic staff of the Ambon State Polytechnic. Willingness and good cooperation to facilitate the research process are highly valued. 


\section{References}

[1] Sumardjoko, B. (2010b). Contribution of Leadership and Organizational Culture through Competence to the Role of Lecturers in Quality Assurance at PTS in the Surakarta Residency. Jurnal Varia Pendidikan, 22(1).

[2] Sulaiman, A., Wibowo, Budi, Udik (2016). Implementation of the Internal Quality Assurance System as an Effort to Improve the Quality of Education at Gadjah Mada. Akuntabilitas Manajemen Pendidikan, 4(1), 17-32.

[3] Gumiandari, S. (2013). Leadership Commitment in Implementing Higher Education Quality Assurance (Case Study of Sheikh Nurjati Cirebon IAIN Cirebon). Holistik, 14(2), 27-56.

[4] Widodo, H. (2015). Portrait of Education in Indonesia and Its Readiness in Facing the Asian Economic Community (AEC), Cendekia, 13(2), 29

[5] Gunawan, J. (2017). National Policy for Higher Education Quality Assurance System. Jakarta: Directorate of Quality Assurance.

[6] Gumiandari, S. (2013). Leadership Commitment in Implementing Higher Education Quality Assurance (Case Study of Sheikh Nurjati Cirebon IAIN Cirebon). Holistik, 14(2), 27-56.

[7] Wicaksono, G. W., \& Al-Rizki, M. A. (2018). Quality Improvement of Academic Quality Evaluation of University of Muhammadiyah Malang Through Quality Information System (SIMUTU). Jurnal Kinetik: Game Technology, Information System, Computer Network, Computing, Electronics, and Control, 1(1), 1-8.

[8] Budiarto, G., Yulianda, F., \& Zulbainarni, N. (2018). Synchronization Strategy for Implementation of Internal Quality Assurance System (IQAS) with ISO 9001 Undergraduate Program of IPB. Jurnal Aplikasi Bisnis dan Manajemen (JABM), 4(2), 202.

[9] Kardoyo, K. (2016). Quality Assurance Analysis of the Faculty of Economics: Achieving Academic Quality Goals and Conformity to Academic Procedures with ISO 9001 Quality Standards: 2008. Journal of Educational Dynamics, 6(2), 108-118.

[10] Ekroman, S. S. (2007). Quality Assurance in the Higher Education System: Jakarta, Depdiknas.

[11] Suti, M. (2011). Quality Improvement Strategies in the Era of Educational Autonomy. Jurnal Medtek, 3(2).

[12] Suci, A. 2017. Higher Education Quality Assurance: The Political Dilemma of Organizations and the Urgency of Using External Professionals. Journal of Quality Assurance, 3(2), 215-222.

[13] Serafimovska, H., \& Ristova, E. (2011). The impact of leadership on achieving total quality management. MTM International Virtual Journal, 5(3), 3-6.

[14] Muhammad, S. (2014). Leadership in the Higher Education Quality Assurance System. Widya 2(3), 56-67.

[15] Tampi, J., Bryan (2014). Effect of Leadership Style and Motivation on Employee Performance at PT. Bank Negara Indonesia, Tbk (Regional Sales Manado). Acta Diurna, III(4), 1-20.

[16] Lasrado, F. (2015). Role of managerial leadership in promoting quality: Experience from Quality Award winning organization in UAE. Research Online, 159-167.

[17] Robbins, P. Stephen. 2003. Organization Behaviour: Concept, Controversies, Aplications. Seventh Edition. Prentice Hall Inc

[18] Taylor, A., \& Hill, F. M. (1992). Implementing TQM in Higher Education. International Journal of Educational Management, 6(4), null. doi: 10.1108/09513549210014673

[19] Bennet, A. B., David 2004. Organizational Survival in The New World Theintelligent Complex Adaptive System. Burlington, MA 01803: KMCI Press.

[20] Bush, Tony. \& Middlewood, David. 2005. Leading and Managing People in Education. First Edition. SAGE Publications Inc. California, USA.

[21] Koesmono, H. T. (2006). The influence of organizational culture on motivation and job satisfaction and employee performance in the sub-sector of the medium-scale wood processing industry in East Java. Management and entrepreneurship journal, 7(2), pp. 171-188.

[22] Hati, S. W. (2013). Effect of Leadership and Lecturer Performance on Service Quality at Batam State Polytechnic. IQTISHODUNA 9(2): 176-184. 
[23] Satyawati, N. M. R., \& Suartana, I. W. (2014). Effect of Leadership Style and Organizational Culture on Job Satisfaction that Impacts Financial Performance . E-Jurnal Akuntansi, 17-32.

[24] Widodo, H. (2015). Portrait of Education in Indonesia and Its Readiness in Facing the Asian Economic Community (AEC), Cendekia, 13(2), 29

[25] Widiyanti, E., Murwati, M., \& Raharjo, T. J. (2018). The Influence of Principal Leadership, School Culture through Motivation on Junior High School Teacher Performance. Educational Management, 7(1), 11-16.

[26] Setyawan, J. D., Sumaryanto, T., \& Murwatiningsih, M. (2017). Autocratic Leadership Style in School Management in Supporting Pancasila Vocational School Teacher Performance in Purwodadi City. Educational Management, 6(2), 190-195.

[27] Suti, M. (2011). Quality Improvement Strategies in the Era of Educational Autonomy. Jurnal Medtek, 3(2).

[28] Suci, A. 2017. Higher Education Quality Assurance: The Political Dilemma of Organizations and the Urgency of Using External Professionals. Journal of Quality Assurance, 3(2), 215-222.

[29] Garwe, E. C. 2014. The Effect of Institutional Leadership on Quality of Higher Education Provision. Research in Higher Education Journal, 22.

[30] Sulaiman, A., Wibowo, Budi, Udik (2016). Implementation of the Internal Quality Assurance System as an Effort to Improve the Quality of Education at Gadjah Mada. Akuntabilitas Manajemen Pendidikan, 4(1), 17-32.

[31] Istiqomah, D. N., Ekosiswoyo, R., \& Pramono, S. E. (2019). Influence of School Culture, Headmaster Supervision and Interpersonal Communication Towards Teacher's Social Behavior. Educational Management, 8(1), 8-16.

[32] Widiyanti, E., Murwati, M., \& Raharjo, T. J. (2018). The Influence of Principal Leadership, School Culture through Motivation on Junior High School Teacher Performance. Educational Management, 7(1), 11-16.

[33] O'Sullivan, D. (2017). Evolution of Internal Quality Assurance at One University - a Case Study. Quality Assurance in Education 25(2): 189-205. https://doi.org/10.1108/QAE-03-20160011

[34] Sulistyaningsih, S., Dewi, A. S., \& Wijayanti, Y. T. (2012). Effect of Organizational Culture on Employee Performance at Sunan Kalijaga UIN Yogyakarta. Journal of Reflective Sociology, $8(2)$.

[35] Garwe, E. C. 2014. The Effect of Institutional Leadership on Quality of Higher Education Provision. Research in Higher Education Journal, 22.

[36] Istiqomah, D. N., Ekosiswoyo, R., \& Pramono, S. E. (2019). Influence of School Culture, Headmaster Supervision and Interpersonal Communication Towards Teacher's Social Behavior. Educational Management, 8(1), 8-16.

[37] Ndapaloka, V., Hardyanto, W., \& Prihatin, T. (2016). The Influence of Academic Supervision of the Supervisory and Headmaster Through Achievement Motivation as Mediation on the Performance of Teachers in the Ende District Vocational School. Educational Management, 5(1), 42-54.

[38] Sumardjoko, B. (2010a). Determinants of the Role of Lecturers in Higher Education Quality Assurance. Education Horizon (3).

[39] Suci, A. 2017. Higher Education Quality Assurance: The Political Dilemma of Organizations and the Urgency of Using External Professionals. Journal of Quality Assurance, 3(2), 215-222. 